\title{
Marker Compounds Adsorbed on Dust Particles (PM10) Sampled According to Standard EN 12341 in the Outdoor Air Near the Cement Plant
}

\author{
Ernest Vončina \\ National Laboratory of Health, Environment and Food (retired)* \\ *Corresponding author: E-mail: ernest.voncina@gmail.com, \\ phone +386 51371641
}

Received: 05-16-2021

\begin{abstract}
Compounds adsorbed onto PM10 in the air near the cement plant were determined. Several side reactions that occur in the hot flue gas stream at the same time as the actual main reactions are also possible. This leads to the formation of traces of organic nitrogen compounds. For the GC/MS determination of polar organic compounds silylation as a derivatization method was used. Organic compounds detected are derivatives of sugars, sugar alcohols, and mono-, di- and tri-carboxylic acids. The composition is characteristic for pollution of the urbane atmosphere. Nitrogen organic compounds formed during the urea thermolytic process in hot cement kiln gases represent parabanic acid, 5-hydroxyhydantoin, 4,5-dihydroxyhydantoin, 5-oxoproline, and cyanuric acid. The inorganic part of aerosols detected includes oxyanions of sulfamic acid, sulfate, sulfite, phosphate, and vanadate $(\mathrm{V})$ with ammonium as a cation.

Chemical compositions of particles are crucial to assess the health impacts since the biological responses to aerosols are not always linked with major constituents but rather with toxicologically potent minor components.
\end{abstract}

Keywords: PM10; cement; SNCR; sulfamic acid; vanadic(V) acid; parabanic acid

\section{Introduction}

Stationary monitoring networks use the mass concentration of PM2.5 or PM10 as the metric and particles are treated as equally toxic, without regard to their source and chemical composition. ${ }^{1,2}$ Airborne particles vary in chemical composition, their solubility and reactivity, mass, size, number, shape and surface area depending upon the source and atmospheric processing. All of these properties have the potential to influence health. The recommended general analytical parameters for the control of cement sector environmental pollutants have been issued and are presented in Table 1. Knowledge of detailed chemical compositions of particles is crucial to assess the health impacts since the biological responses to aerosols are not always linked with major constituents, but rather with toxicologically potent minor components.

The capability of PM to induce disease may be the result of multiple components acting through different physiological mechanisms. It is important to determine which components and sources of PM are most harmful since the identification of regulation targets can better protect human health.

After gravimetric determination of PM10, the chemical composition of the adsorbed organic fraction on PM10 in the air near cement plant was determined. ${ }^{3}$ The aim of the study was to find specific marker compounds for cement kiln emissions. Cement plant emission monitoring is obligatory to demonstrate compliance with existing laws, regulation, and agreements. Co- incineration of hazardous wastes should only be performed if the cement kiln operates according to the best available techniques. ${ }^{4}$ The suitability of the production site must be assessed to avoid risks associated with a potential release of vapours and odours or the possibility of leaks that might release hazardous waste or other substances of concern into the environment. Requiring control of technical solutions should be in accordance with the best available technology associated emission levels (BAT-AEL). The recent recommended values for the cement sector environmental pollutants have been issued and are presented in Table1.

Small quantities of ammonia can be observed in the flue gas from cement kilns. The ammonia originates from 
Table 1. The BAT-AEL are 24-hour average values referred to dry gas in standard conditions $\left(0{ }^{\circ} \mathrm{C}, 100 \mathrm{kP}\right)$ and $10 \%$ oxygen.

\begin{tabular}{lc}
\hline Environmental pollutants & BAT-AEL $\left(\mathbf{m g} / \mathbf{N m}^{3}\right)$ \\
\hline Total dust & $<10-20$ \\
$\mathrm{NO}_{\mathrm{x}}\left(\mathrm{NO}, \mathrm{NO}_{2}, \mathrm{NO}_{\mathrm{x}}\right.$, expressed as $\left.\mathrm{NO}_{2}\right)$ & $200-450$ \\
$\mathrm{SO}_{2}$ & $50-400$ \\
$\mathrm{HCl}$ & 10 \\
$\mathrm{HF}$ & 1 \\
$\mathrm{Sb}+\mathrm{AS}+\mathrm{Pb}+\mathrm{Cr}+\mathrm{Co}+\mathrm{Mn}+\mathrm{Ni}+\mathrm{V}$ & 0.5 \\
$\mathrm{Cd}+\mathrm{Tl}$ & 0.05 \\
$\mathrm{Hg}$ & 0.05 \\
$\mathrm{PCDD}$ and PCDF (dioxins and furans) & $0.05-0,1\left(\mathrm{I}-\mathrm{TEQ} \mathrm{ng} / \mathrm{Nm}^{3}\right)$ \\
$\mathrm{NH}$ & (ammonia slip from injection system) \\
\hline
\end{tabular}

the pyrolysis of nitrogenous fuels and raw materials or from reagents used for denitrification of $\mathrm{NO}_{\mathrm{x}}$ gases. ${ }^{5,6}$ With the combustion of fossil fuels, massive harmful emissions of nitrogen oxides $\left(\mathrm{NO}_{\mathrm{x}}\right)$, mainly including $\mathrm{NO}$ and $\mathrm{NO}_{2}$, have been discharged into the atmosphere. To reduce the severe $\mathrm{NO}_{\mathrm{x}}$ emission techniques, such as selective catalytic reduction (SCR) and selective non-catalytic reduction (SNCR) were developed. ${ }^{7,8}$

Injection of higher values of urea can improve $\mathrm{NO}_{\mathrm{x}}$ reduction but may also increase ammonia slip. Reduction chemistry is a relatively simple chemical process. The process begins with an ammonia-based reagent, ammonia or urea, being vaporized within the appropriate temperature range, the gas-phase urea or ammonia then decomposes into free radicals, including $\mathrm{NH}_{3}$ and $\mathrm{NH}_{2} \cdot{ }^{9}$ After a series of reactions, the ammonia radicals come into contact with the $\mathrm{NO}_{\mathrm{x}}$ and reduce it to $\mathrm{N}_{2}$ and $\mathrm{H}_{2} \mathrm{O}$. Since $\mathrm{NO}_{\mathrm{x}}$ includes both $\mathrm{NO}$ and $\mathrm{NO}_{2}$, the main overall stoichiometric reactions with urea and ammonia are as follows $(1,2)$ :

$$
\begin{aligned}
& 2 \mathrm{NO}+2 \mathrm{NH}_{3}+1 / 2 \mathrm{O}_{2} \rightarrow 2 \mathrm{~N}_{2}+3 \mathrm{H}_{2} \mathrm{O} \\
& 2 \mathrm{NO}_{2}+4 \mathrm{NH}_{3}+\mathrm{O}_{2} \rightarrow 3 \mathrm{~N}_{2}+6 \mathrm{H}_{2} \mathrm{O}
\end{aligned}
$$

Several side reactions that occur in the hot flue gas stream at the same time as the actual main reactions are also possible. This leads to the formation of traces of organic nitrogen compounds. The aim of the study was to find specific marker compounds for cement kiln emissions, which show the difference according to the composition of the surrounding air in the broader area.

\section{Experimental Section}

\section{1. Sample Collection and Weather Conditions at the Time of Measurements}

Aerosol samples were collected at a distance of approximately $550 \mathrm{~m}$ in a south-westerly direction from the central chimney of the clinker furnace. An air sample was tak- en at the height of 1.5 meters above ground level. Sampling was achieved under the operating conditions of the rotary kiln from 06/07/2015, starting around $2 \mathrm{pm}$ and ending on $09 / 07 / 2015$ at $2 \mathrm{pm}$. Three consecutive samples (sample 01 , sample 02, sample 03) were taken, each within 24 hours. Sampling sites are illustrated in Figure 1.

Meteorological data were monitored during the measurements at 10 min intervals. In Figure 1, the wind rose diagram shows the general wind direction and the wind direction frequency of blowing between each sampling period. The weather conditions at the time of sampling were different; the first two days (sample 01 and sample 02) the SW wind blew with low speed, while the last day (sample 03) the wind turned in the NE direction and was intensified. Measured wind speed was from 5 to 25 $\mathrm{m} / \mathrm{s}$; the air temperature was between 20 to $34^{\circ} \mathrm{C}$ and relative humidity $50-95 \%$ during sampling time.

\section{2. Sampling of Particulate Matter PM10}

The research included samples of particulate matter PM10 collected according to standard EN 12341:2014 using low-volume air sampler (TCR Tecora Skypost PM, Leckel SEQ 47/50) with a flow rate of $38.3 \mathrm{~L} / \mathrm{min}$.

Aerosol samples were collected on quartz filters (Munktell, quartz microfiber discs, $47 \mathrm{~mm}$ ) during the period from day 06/07/2015 with beginning at $2 \mathrm{pm}$ and finished on $09 / 07 / 2015$ at $2 \mathrm{pm}$. Three samples were gathered consecutively; each sample was collected within 24 hours. All experimental devices, including a low-volume air sampler probe and glassware, were pre-extracted with dichloromethane. A reagent blank was analysed before sample analysis in each batch. Quartz filters were combusted before use at $500{ }^{\circ} \mathrm{C}$ for six hours. After the gravimetric determination of PM10 particles (Standard EN 12341:2014) the collected samples were placed in a glass vial with a Teflon cap and stored at $-20{ }^{\circ} \mathrm{C}$ prior to analysis. Samples were extracted three times $(3 \times 20 \mathrm{~mL})$ using a shaker with orbital movement with a mixture of dichloromethane/methanol (2:1 $\mathrm{v} / \mathrm{v})$. On a rotary evaporator, the combined extracts were evaporated to dryness. Dry residues of extracts were dis- 


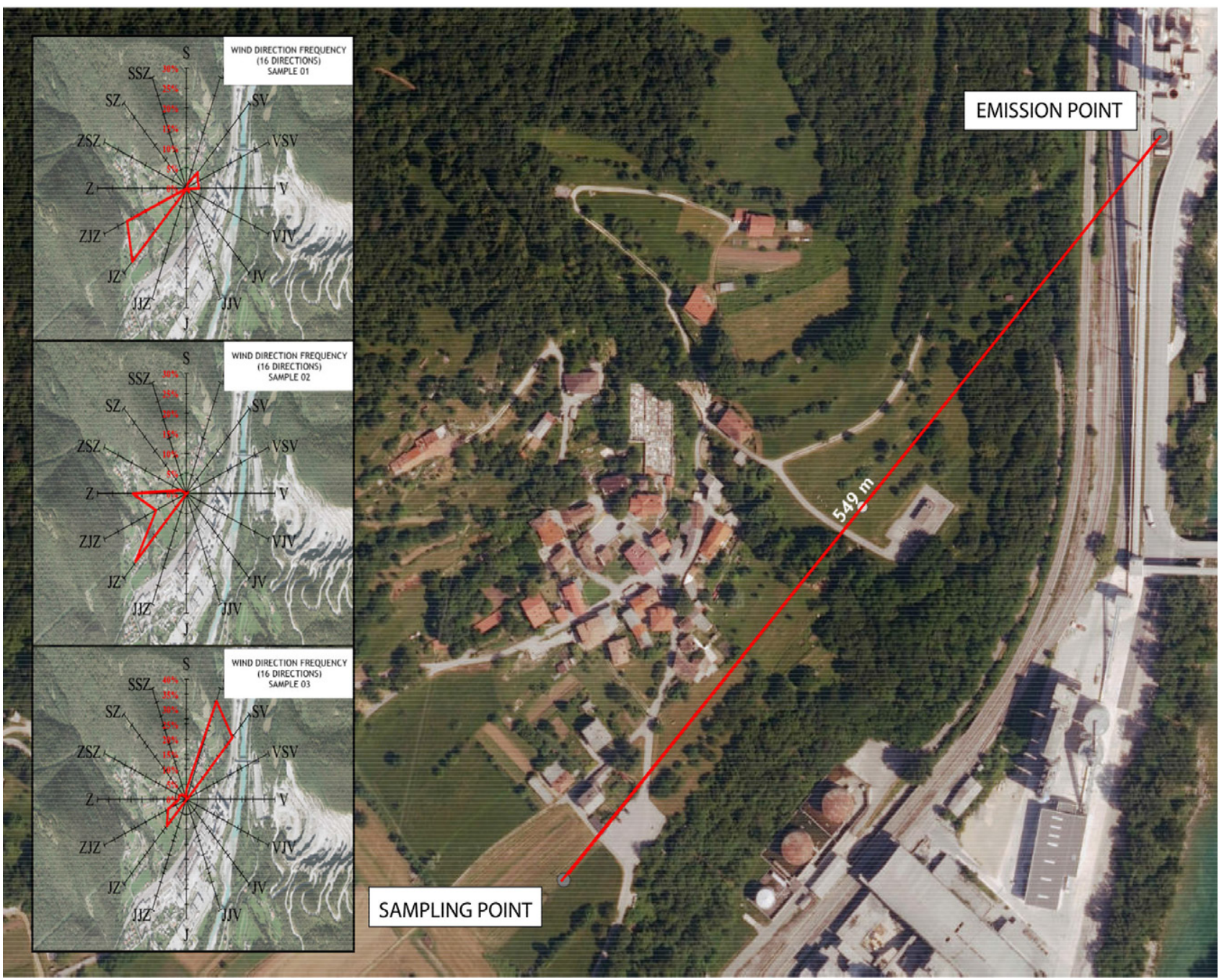

Figure 1. Position of the sampling point, the direction and distance to the emission source. Left: wind roses diagram for sample 01,02 and 03 from 6. July to 9 . July 2015. http://gis.arso.gov.si/atlasokolja/.

solved in pyridine and derivatised with MSTFA ( $N$-methyl- $N$-trimethylsilyl trifluoroacetamide) for one hour at 60 ${ }^{\circ} \mathrm{C}$. Concentrated and derivatized extracts with a final volume of $100 \mu \mathrm{L}$ were quantitatively transferred into a glass vial and analysed with GC/MS.

\section{3. Instrumental Analysis}

Agilent (5973) mass spectrometer connected to a gas chromatograph Agilent (6890) and Agilent autosampler (7683) was used. For the chromatographic separation, an Agilent capillary column DB-UI 8270 D with the dimensions of $30 \mathrm{~m}$ and an internal diameter of $0.25 \mathrm{~mm}$ and a film thickness of stationary phase $0.25 \mu \mathrm{m}$ was used. The temperature program was following: $0.75 \mathrm{~min}$ at a temperature of $105^{\circ} \mathrm{C}, 30^{\circ} \mathrm{C} / \mathrm{min}$ up to $120^{\circ} \mathrm{C}(0.1 \mathrm{~min}), 2.7$ ${ }^{\circ} \mathrm{C} / \mathrm{min}$ to $320^{\circ} \mathrm{C}$ (5 min). The carrier gas was helium (He 6.0, Messer Austria) at a constant flow of $0.9 \mathrm{ml} / \mathrm{min}$. The ion source temperature was $250^{\circ} \mathrm{C}$. The injection port and transfer line were kept at $290^{\circ} \mathrm{C}$. The mass spectrometer was operated in electron ionization (+EI) mode at $70 \mathrm{eV}$ and scanned in full scan mode in the range 70-800 Da. Chromatograms were processed by a computer program AMDIS (Automated Mass Spectral Deconvolution and Identification System Software). Detected compounds were identified by comparing their spectra with those reported in the Willey and NIST (W10N14) standard mass spectra database and with data in the literature or by own spectra interpretation. The reported mass spectra showed a good mass spectral match quality, better than 90 .

\section{Results and Discussion}

\section{1. Influences of the Urbane Background Atmosphere}

At the time of measurements, weather conditions were different, the first two samples were gathered when SW wind blowing, while the third sample was gathered 
when NE wind was blown. When the wind has turned from SW to NE in the direction to sampling point, in the extract of sample 03 a group of nitrogenous organic compounds traces was detected. From the review of detected compounds in all three chromatograms of sample 01,02 and 03 (Figure 2 and Figure 3) the most intensive polar organic compounds are derivatives of sugars, sugar alcohols and mono-, di- and tri-carboxylic acid. Carboxylic acids are frequently present in atmospheric aerosol samples. These compounds could be oxidation products from

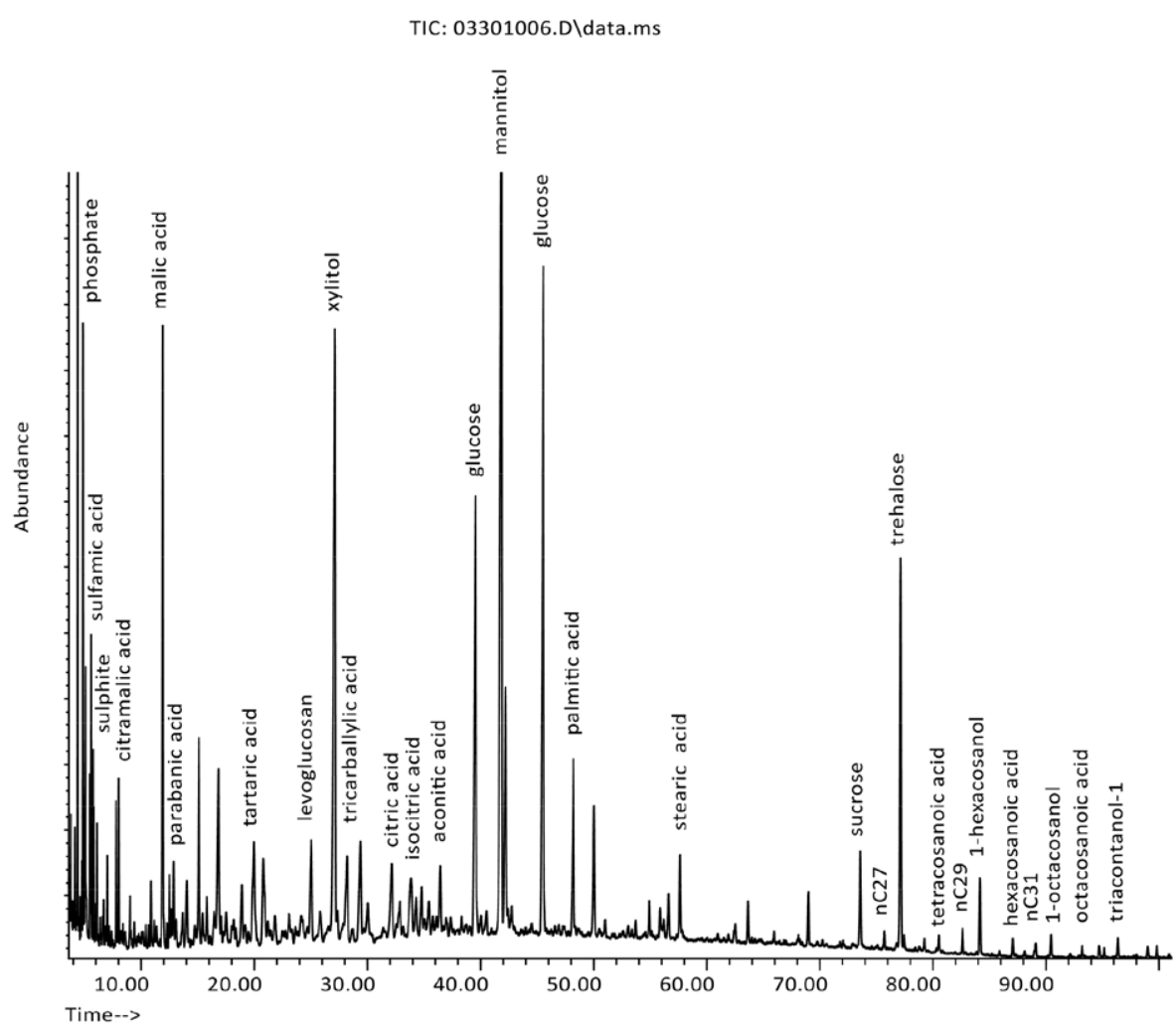

Figure 2. GC/MS total ion chromatograms showing trimethylsilylated derivatives observed in the extract in sample 03 .

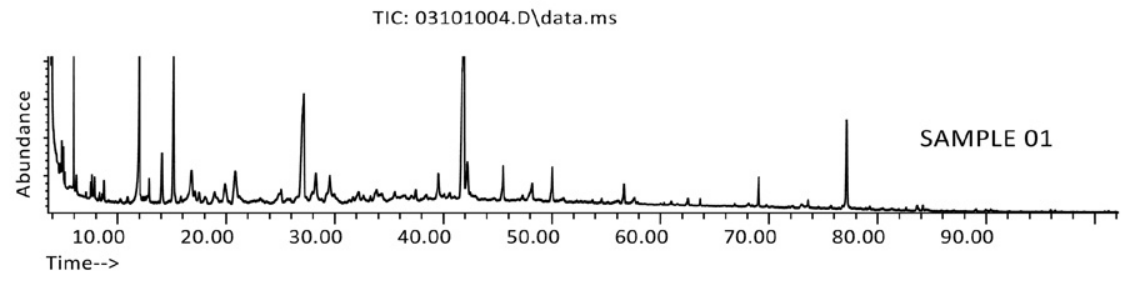

TIC: 03201005.D\data.ms $\left({ }^{*}\right)$

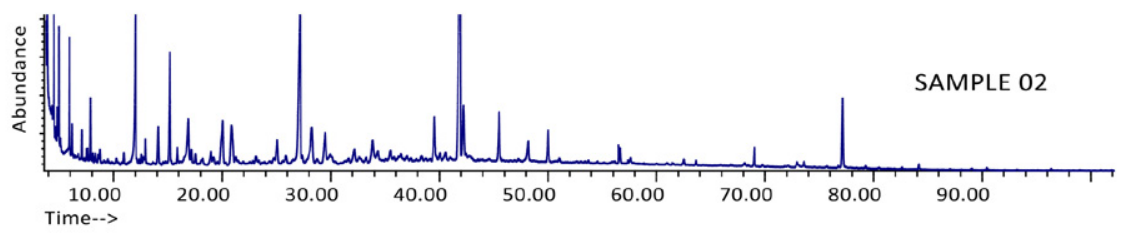

TIC: 03301006.D\data.ms $\left({ }^{*}\right)$

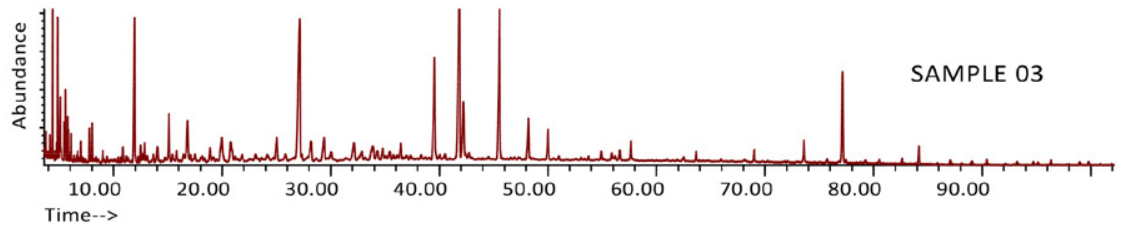

Figure 3. Comparison of the total ion chromatogram (TIC) between samples 01, 02 and 03 . 
biopolymers or incomplete combustion product, and they could represent secondary organic compounds formed by photochemical reactions. ${ }^{10,11}$ The presence of $n$-alkanes and a fraction of polycyclic aromatic compounds $(\mathrm{PAH})$ is low, at detection limit of the experimental method. It is related to the summer season, when there is no use of fossil fuels for heating and at the same time the photochemical degradation is high. Compounds are characteristic for pollution of the urbane atmosphere and show the impact of different sources such as traffic, various industrial processes, incineration, and energetic production system. Several comprehensive reviews on the topic of the presence, formation, and composition of atmospheric aerosols exist. $12,13,14$

\section{2. Influences of the Cement Plant Emmisions}

Ammonia is the most abundant basic gas which participates in acid-base reactions in the condensed phase on atmospheric particle matter. Condensable particulate matter is not directly emitted as a solid or liquid at the stack. Instead, gaseous emissions such as sulfuric acid, sulfamic acid, ammonium sulfate or sulfamate and certain metal vapours condense upon cooling and dilution in the ambient air to form solid or liquid particles following discharge from the stack. The inorganic part of aerosols detected in sample 03 as TMS derivatives include sulfamic acid (Figure 4), sulfite, sulfate, phosphate and to lesser extent vanadate(V) (Figure 5). Ammonia catalyzes the atmospheric oxidation of sulfur dioxide to sulfur trioxide and reacts rapidly with acidic components of the atmosphere. The ammonium salts as components of aerosols are formed. ${ }^{15}$ Because the concentration of water is greater than the concentration of ammonia, under normal atmospheric conditions, $\mathrm{SO}_{3}$ will react predominantly with water, not with ammonia. Under the conditions expected during a massive release of ammonia, the reaction of $\mathrm{SO}_{3}$ (a strong Lewis acid) with ammonia (a good electron pair donor) sulfamic acid is formed (3). ${ }^{16}$

$$
\begin{aligned}
& \mathrm{NH}_{3}(\mathrm{~g})+\mathrm{SO}_{3}(\mathrm{~g}) \rightarrow{ }^{+} \mathrm{NH}_{3}-\mathrm{SO}_{3}{ }^{-}(\mathrm{g}) \rightarrow \\
& \rightarrow \mathrm{H}_{2} \mathrm{~N}-\mathrm{SO}_{3} \mathrm{H}(\mathrm{s})
\end{aligned}
$$

The vanadium content in soils and waters is primarily determined by the geological parent material. Anthropogenic emissions, mainly from the combustion of fossil fuels or industry processes, may enhance soil vanadium concentrations locally. Vanadium is an essential element that has beneficial effects at low concentration but becomes toxic when present in higher amounts. Vanadium in tetravalent and pentavalent oxidation states, especially as ammonium salt in the environmental samples as are aerosol particles, are water soluble and toxic. Speciation analysis of this element is important for evaluating the potential risk to the environmental and biological systems rather than determining total vanadium contents. ${ }^{17-21}$

Urea pyrolysis reaction $(4,5)$ plays an important role in the urea-based $\mathrm{NO}_{x}$ removal process.

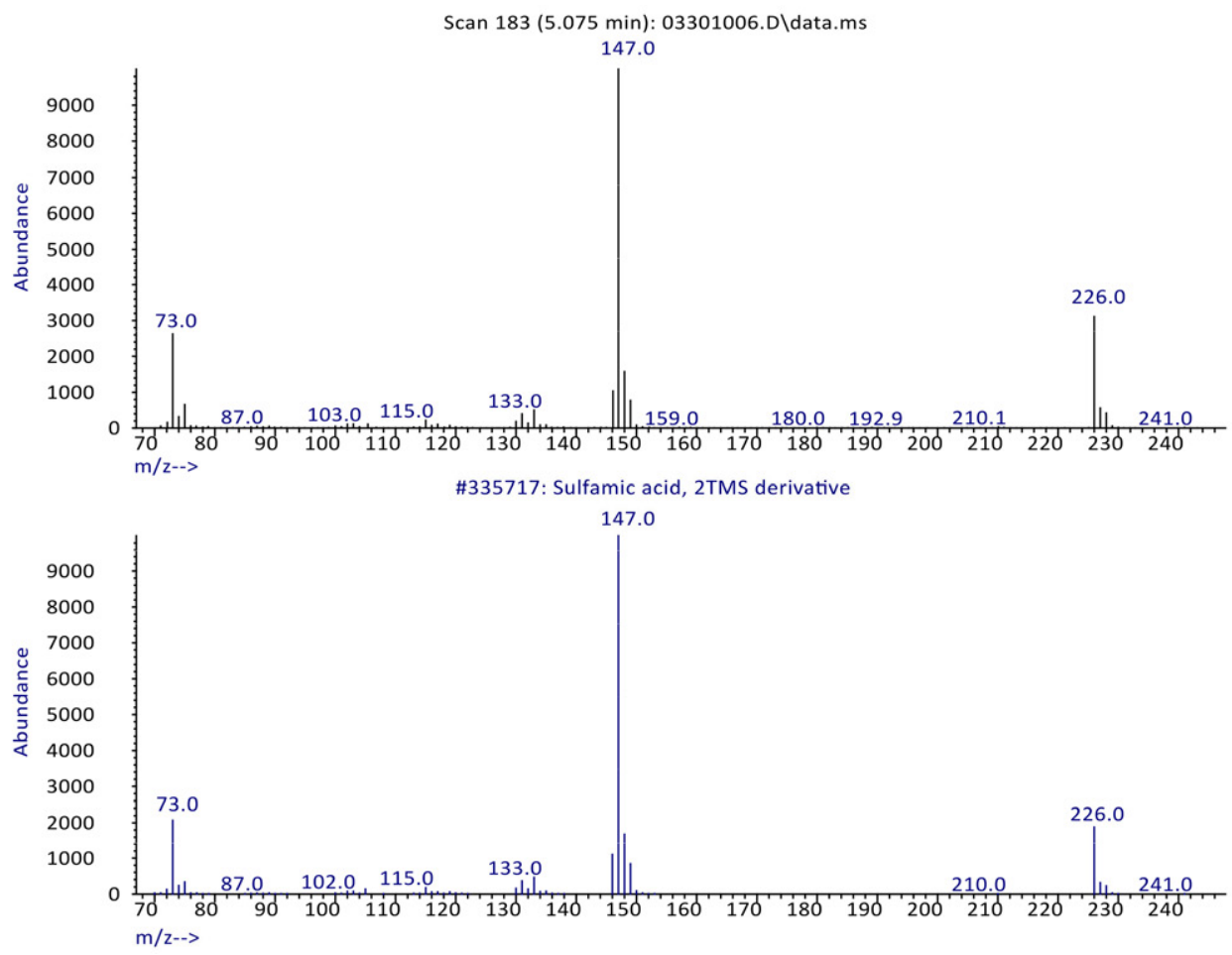

Figure 4. Mass spectrum comparison of sulfamic acid in sample 03 and Willey-NIST library mass spectral data. 


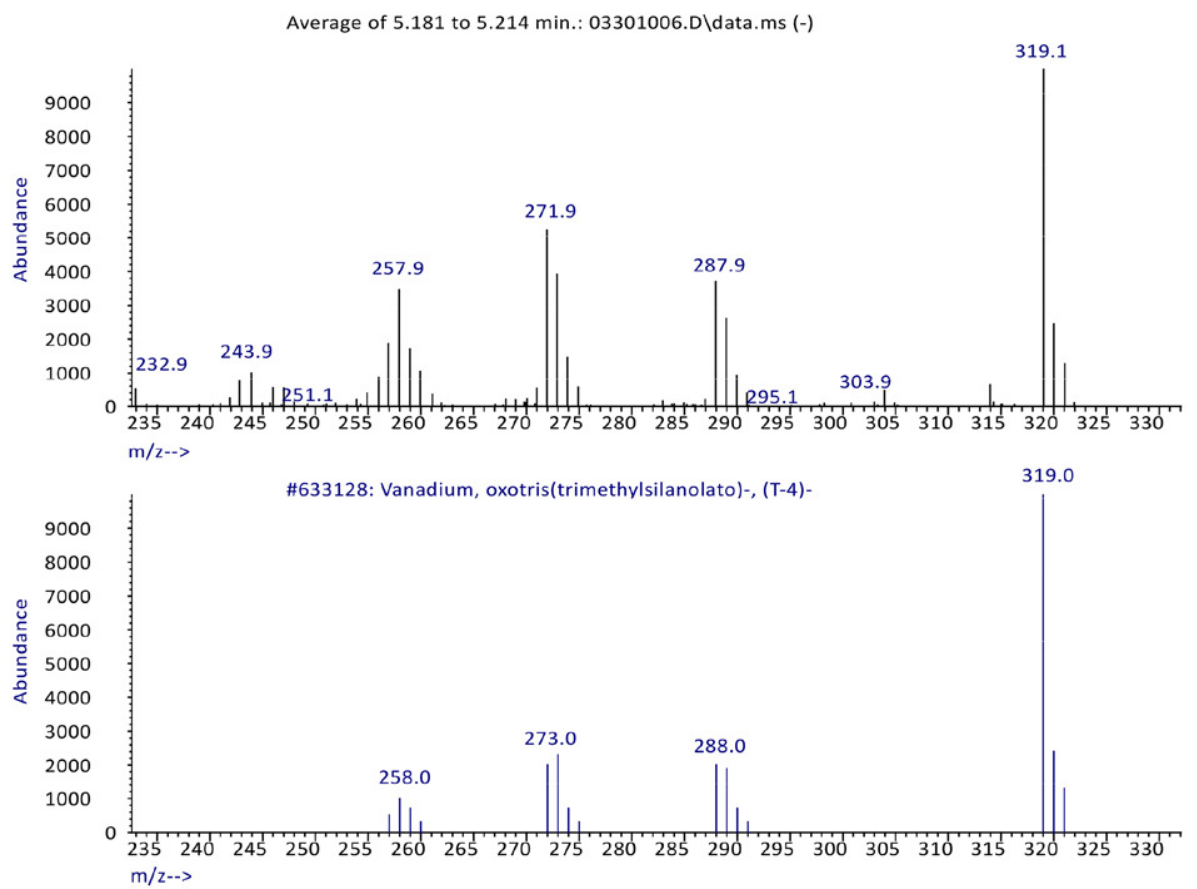

Figure 5. Mass spectrum comparison of vanadic(V) acid 3TMS derivative in sample 03 and Willey-NIST library mass spectral data.<smiles>O=C1NC(=O)C(=O)N1</smiles>

a)<smiles>O=C1NC(=O)C(O)N1</smiles>

b)<smiles>O=C1NC(O)C(O)N1</smiles>

c)<smiles>O=C1CCC(C(=O)O)N1</smiles>

d)<smiles>O=c1[nH]c(=O)[nH]c(=O)[nH]1</smiles>

e)

Figure 6. The formation tentatively involves the condensation reaction of urea and glyoxal, hydrated glyoxal or oxalic acid as a reactant. Imidazoline-2,4,5-trione (a) 5-hydroxy-2,4-imidazolidindione (b), 4,5-dihydroxy-2-imidazolidinone (c), 5-oxo-proline (d) and cyanuric acid (e) as a side reaction of urea thermolytic decomposition were also detected.
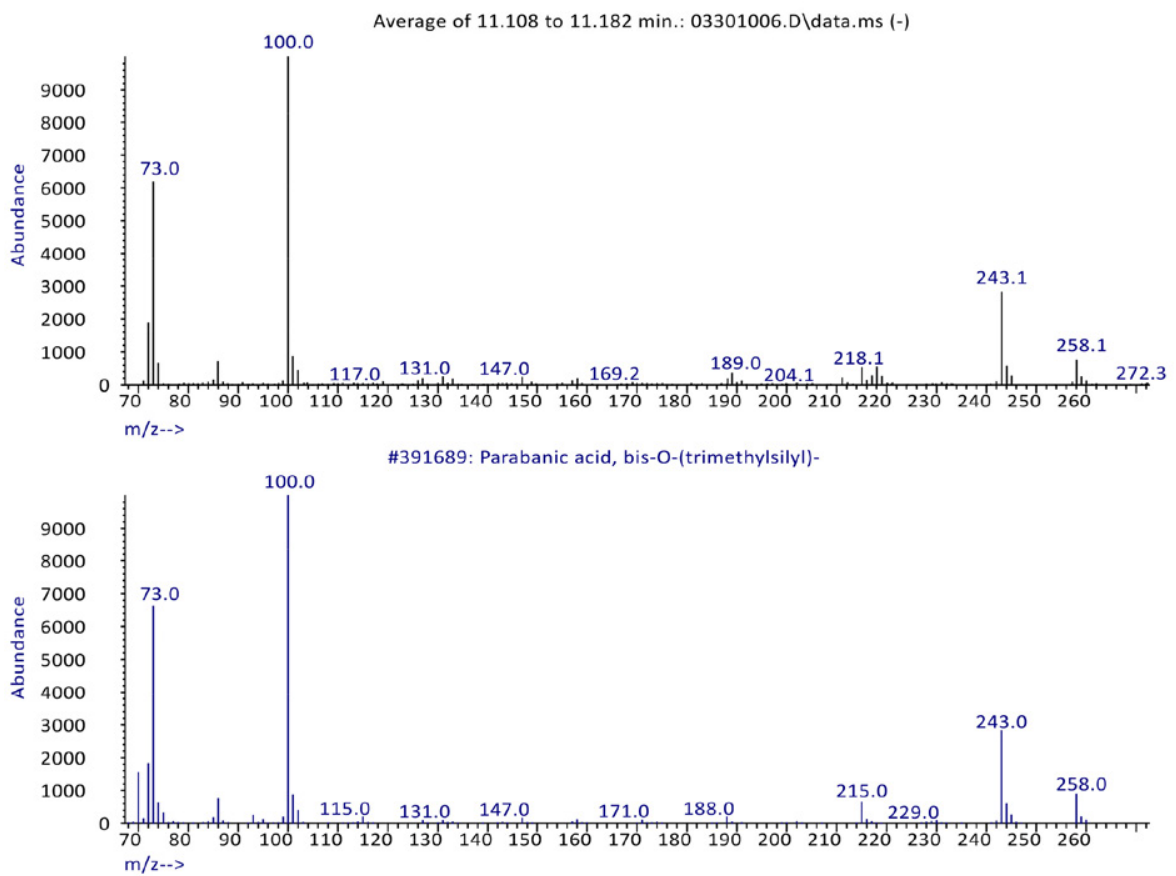

Figure 7. Mass spectrum comparison of imidazolidine-2,4,5-trione 2TMS derivative (parabanic acid 2TMS) in sample 03 and Willey-NIST library mass spectral data. 


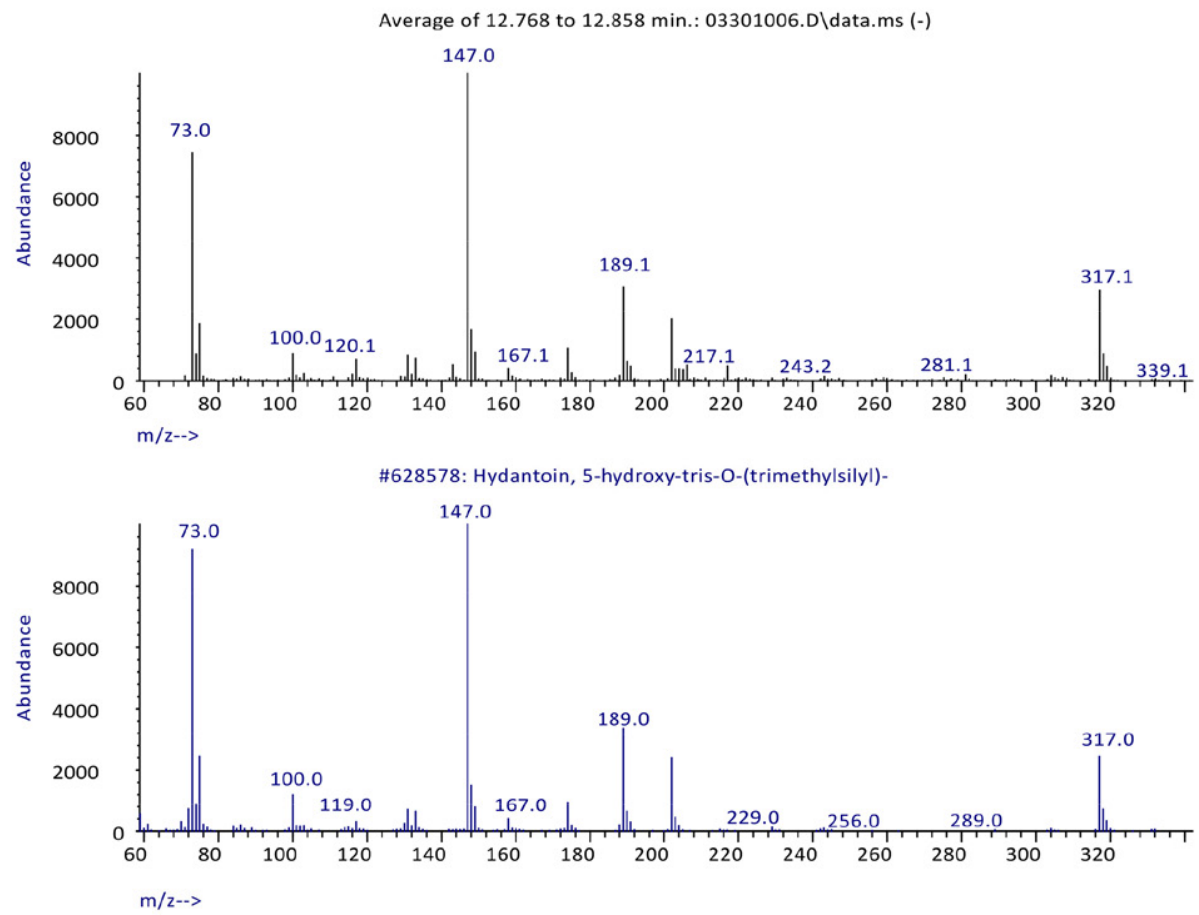

Figure 8. Mass spectrum comparison of 5-hydroxy-hydantoin 3TMS derivative in sample 03 and Willey-NIST library mass spectral data.

$$
\begin{aligned}
& \mathrm{NH}_{2} \mathrm{CONH}_{2} \rightarrow \mathrm{NH}_{3}+\mathrm{HNCO} \\
& \mathrm{HNCO}+\mathrm{H}_{2} \mathrm{O} \rightarrow \mathrm{NH}_{3}+\mathrm{CO}_{2}
\end{aligned}
$$

Overview of recorded mass spectra gives the presence of nitrogen compounds formed during the urea thermolytic process in hot cement kiln gases (Figure 6,7 and 8).
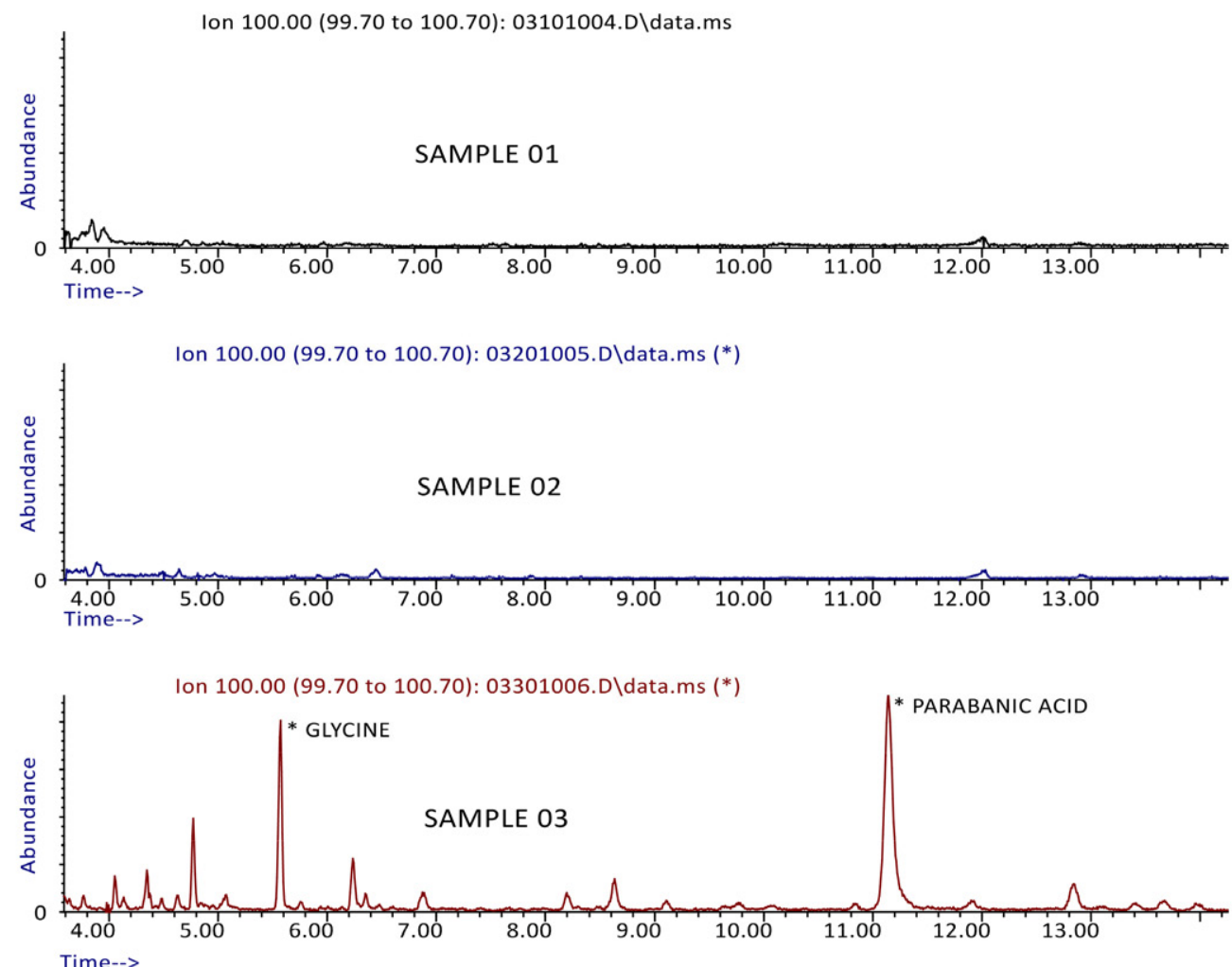

Figure 9. Comparison of ion current of mass fragments $\mathrm{m} / \mathrm{z} 100$ characteristic for silylated derivatives of glycine and parabanic acid TMS derivative from all three sample extracts. 
The number of potential reaction partners in ambient aerosols is high, and the identification of appropriate tracer compounds is necessary to estimate the source of organic compounds. It is expected that imidazolidinone formation from $\alpha$-dicarbonyl compounds and ammonia or urea in aerosols should be favoured in regions with aerosols exhibiting more alkaline $\mathrm{pH}$ values and higher ammonium concentrations which is valid for cement plant emissions.

Three amino acid were detected. The most abundant species are glycine, then $\beta$-alanine and in traces $\gamma$-aminobutyric acid, both as a nonproteinogenic amino acid, formed as degradation of biomass in raw materials or thermic processes. ${ }^{22,23}$ At pyro-processing of raw material in cement plant amino acid decompose thermally, they do not sublimate, nor do they melt. Only three gases are formed, mostly $\mathrm{H}_{2} \mathrm{O}, \mathrm{NH}_{3}$ to a lesser extent, and hardly any $\mathrm{CO}_{2}$. Cysteine forms $\mathrm{H}_{2} \mathrm{~S}$ but not $\mathrm{CS}_{2}$. Thermolytically formed liquid or solid residues are lactams and heterocyclic compounds with 5- or 6-membered non- (or only partially) aromatic rings, containing one or two nitrogen atoms, most of them with peptide bonds present. ${ }^{24}$

Air quality monitoring at fixed sites is a major instrument to check compliance with the limit or target values, which have been set for the protection of human health. ${ }^{25}$ Comparison of the ion current of mass fragments $\mathrm{m} / \mathrm{z} 100$ characteristic for silylated derivatives of glycine and parabanic acid from all three sample extracts is presented in Figure 9. It shows the inadequacy of the position of the monitoring site with respect to the wind conditions at the time of sampling that might lead to different assessments of air pollution exposure.

Monitoring of $\mathrm{NO}_{\mathrm{x}}$ and leak of $\mathrm{NH}_{3}$ gases with determination of organic nitrogen compounds composition can help to control the SNCR or SCR process in cement kiln and to determine different influences on air pollution. It is suggested that surface-monitoring sites should be established downwind and upwind of cement factories to simultaneously monitor their emissions. Our research suggests that additionally to obligatory cement plant emission monitoring program also further, more detailed investigation of the impact of emissions on the environment is strongly recommended.

\section{Conclusions}

With the GC/MS analytical approach, the composition of organic compounds adsorbed onto dust particles sampled according to standard EN 12341 in the outdoor air near the cement plant was determined. Recorded mass spectra show the presence of nitrogen compounds formed during urea thermolytic process in hot cement kiln gases. Parabanic acid (imidazoline-2,4,5-trione), 5-hydroxyhydantoin (5-hydroxy-2,4-imidazolidindione), 4,5-dihydroxyhydantoine (4,5-dihydroxy-2-imidazolidinone), 5-oxo-proline and cyanuric acid as a side reaction of urea thermolytic decomposition were detected in sample 03 . Amino acid detected were glycine, $\beta$-alanine and traces $\gamma$-aminobutyric acid. The inorganic part of aerosols detected in sample 03 as TMS derivatives include in descendent order: sulfamic acid $>$ sulfate $>$ sulfite $>$ phosphate and to a lesser extent vanadate $(\mathrm{V})$. Special attention should be devoted to the presence of vanadate $(\mathrm{V})$ oxyanion and sulfamic acid. The particle matter toxicity derives not only from the physical presence of particles on biological tissues but also from the toxic effects of chemical constituents. Knowledge of detailed chemical compositions of particles is crucial to assess the health impacts since the biological responses to aerosols are not always linked with major constituents, but rather with toxicologically potent minor components. This demonstrates the necessity of the identification of organic compounds at trace levels to enable a better understanding of relevant air pollution processes.

\section{References}

1. Directive 2008/50/EC of the European Parliament and of the Council of 21 May 2008 on ambient air quality and cleaner air for Europe, OJ L 152, 2008, pp. 1-44.

2. SIST EN 12341:2014, Ambient air - Standard gravimetric measurement method for the determination of the PM10 or PM2,5 mass concentration of suspended particulate matter, https://standards.iteh.ai/catalog/standards/sist/5d138eac4d44-4419-a069-eb23d01a9b0c/sist-en-12341-2014 (accessed January 3, 2021)

3. A. Miuc, E. Vončina, U. Lešnik, Acta Chim. Slov. 2015, 62, 834-848. DOI:10.17344/acsi.2015.1542

4. Best available techniques (BAT) reference document for the production of cement, lime and magnesium oxide: Industrial emissions directive 2010/75/EU: (Integrated Pollution Prevention and Control), pp. 1-480. DOI:10.2788/12850

5. E. Borrás, L. A. Tortajada-Genaro, F. Sanz, A. Muñoz, Atmosphere 2021, 12, 94, 1-15. DOI:10.3390/atmos12010094

6. B. Jiang, D. Xia, Clean Techn Environ Policy 2020, DOI:10.1007/s10098-020-01923-X

7. EPA-456/F-99-006R, November 1999 Nitrogen Oxides (NOx), Why and How They Are Controlled, i-48, (technical bulletin), https://www3.epa.gov/ttncatc1/dir1/fnoxdoc.pdf (accessed January 8, 2021)

8. H. C. Kim, C. Bae, M. Bae, O. Kim, B. U. Kim, C. Yoo, J. Park, J. Choi, J.-bum Lee, B. Lefer, A. Stein, S. Kim, Atmosphere 2020, 11, 881, 2-14. DOI:10.3390/atmos11080881

9. D. Wang, N. Dong, Y. Niu, S. Hui, Hindawi Journal of Chemistry 2019, 1-11. DOI:10.1155/2019/6853638

10. E. Borrás, L. A. Tortajada-Genaro, F. Sanz A. Muñoz, Atmosphere 2021, 12, 2-15, 94, DOI:10.3390/atmos12010094

11. P. Sricharoenvech, A. Lai, T. N. Oo, M. M. Oo, J. J. Schauer, K. L. Oo, K. K. Aye, Int. J. Environ. Res. Public Health ,2020, 17, 4145; DOI:10.3390/ijerph17114145 
12. D. J. Bryant, W. J. Dixon, J. R. Hopkins, R. E. Dunmore, K. L. Pereira, M. Shaw, F.A. Squires, T. J. Bannan, A. Mehra, S. D. Worrall, A. Bacak, H.Coe, C. J. Percival, L. K. Whalley, D. E. Heard, E. J. Slater, B. Ouyang, T. Cui, J. D. Surratt, D.Liu, Z. Shi, R. Harrison, Y. Sun, W. Xu, A.C. Lewis, Atmos. Chem. Phys. 2020, 20, 7531-7552. DOI:10.5194/acp-20-7531-2020

13. T. Schilirò, S. Bonetta, L. Alessandria,V. Gianotti, E.Carraro, G. Gilli, Environmental Toxicology and Pharmacology 2015, 39, 2, 833-844. DOI:10.1016/j.etap.2015.02.00

14. R. Zhang, G. Wang, S. Guo, M. L. Zamora, Q. Ying, Y. Lin, W. Wang, M. Hu, Y. Wang, Chem. Rev. 2015, 115, 3803-3855. DOI:10.1021/acs.chemrev.5b00067

15. J. J. Renard, S. E. Calidonna, M. V. Henley Journal of Hazardous Materials B 2004,108, 29-60.

DOI:10.1016/j.jhazmat.2004.01.015

16. H. Li, J. Zhong, H. Vehkamäki, T, Kurtén, W. Wang, M. Ge, S. Zhang, Z. Li, X. Zhang, J.S. Francisco, X. C. Zeng, J. Am. Chem. Soc. 2018, 140, 35, 11020-11028.

DOI: $10.1021 /$ jacs.8b04928

17. M. A. Larsson, Vanadium in Soils - Chemistry and Ecotoxicity, Swedish University of Agricultural Sciences, 2014, (electronic version), 1-60, https://pub.epsilon.slu.se/11653/1/larsson_ma_141117.pdf (accessed January 8, 2021)

18. X. C. Goso, H. Lagendijk, M. Erwee and G. Khosa Hydrometallurgy Conference 2016: Sustainable Hydrometallurgical Extraction of Metals Cape Town, 1-3 August 2016, 69-79.
Indicative Vanadium Deportment in the Processing of Titaniferous Magnetite by the Roast-Leach and Electric Furnace Smelting Processes.

19. X. Hu, Y. Yue, X. Peng, Environ Sci Pollut. Res. 2019, 26:1789117900. DOI:10.1007/s11356-017-0342-2

20. K. H. Jung, D. Torrone, S. Lovinsky-Desir, M. Perzanowski, J. Bautista, J. R. Jezioro1, L. Hoepner, J. Ross, F. P. Perera, S. N. Chillrud, R. L. Miller, Respiratory Research 2017, 18:63, 1-11. DOI:10.1186/s12931-017-0550-9

21. F. Dominici, R. D. Peng, K. Ebisu, S. L. Zeger, J. M. Samet, M. L. Bell, Environ Health Perspect 2007, 115, 1701-1703. DOI:10.1289/ehp.10737

22. E. Barbaro, R. Zangrando, I. Moret, C. Barbante, P. Cescon, A. Gambaro, Atmospheric Environment 2011, 45, 5050-5057. DOI:10.1016/j.atmosenv.2011.01.068

23. I. M. Weiss, C. Muth, R. Drumm, H. O. K. Kirchner, BMC Biophysics 2018, 11:2, 2-15. DOI:10.1186/s13628-018-0042-4

24. F. J. Kelly, J. C. Fussell, Phil.Trans.R.Soc. 2020, 378:20190322. DOI:10.1098/rsta.2019.0322

25. C. Nagl, W. Spangl, I. Buxbaum, Sampling points for air quality, Study for the Committee on the Environment, Public Health and Food Safety, Policy Department for Economic, Scientific and Quality of Life Policies, European Parliament, Luxembourg, 2019, 1-102, https://www.europarl.europa.eu/RegData/etudes/STUD/2019/631055/IPOL_STU(2019)631055_ EN.pdf (accessed January 5, 2021)

\section{Povzetek}

Cilj študije je poiskati markerske spojine emisij iz cementnih peči, ki kažejo na razliko glede na sestavo okoliškega zraka na širšem območju. Določili smo sestavo organskih spojin adsorbiranih na prašnih delcih PM10, ki so bili odvzeti v skladu s standardom EN 12341:2014 v vzorcih zraka v bližini cementarne. Možnih je tudi več stranskih reakcij, ki se pojavijo $\mathrm{v}$ toku vročih dimnih plinov hkrati z dejanskimi glavnimi reakcijami. To vodi do nastanka sledi organskih dušikovih spojin. Za GC/MS analizo hlapnih in pol hlapnih polarnih spojin smo uporabili sililiranje kot metodo derivatizacije. Glavnino zaznanih spojin predstavljajo spojine sililiranih derivatov sladkorjev, sladkornih alkoholov ter mono-, di- in tri-karboksilnih kislin. Sestava je značilna za onesnaženo urbano ozračje. Med organskimi dušikovimi spojinami, ki nastanejo med termolitskim razpadom sečnine v vročih plinih cementne peči, smo zaznali parabansko kislino, 5-hidroksihidantoin, 4,5-dihidroksihidantoin, 5-oksoprolin in cianurno kislino. Anorganski del aerosolov vključuje sililirane derivate sulfamske kisline, sulfata, sulfita, fosfata in vanadijeve(V) kisline. Podrobna kemijska sestava prašnih delcev PM10 je pomembna za toksikološko oceno vplivov na okolje in zdravje, saj biološki odziv ni vedno povezan s spojinami, ki jih je največ.

Except when otherwise noted, articles in this journal are published under the terms and conditions of the Creative Commons Attribution 4.0 International License 